\title{
A HISTORY OF THE LAW FACULTY
}

\section{JOHN M. LAW and RODERICK J. WOOD'}

The authors examine the history of the Faculty of Law at the University of Alberta. Beginning with a look at the early requirements to practice law in Alberta, the authors discuss the events leading to the establishment of the first permanent law school in the province. An analysis of the evolution of the Faculty is conducted. Along the way, the important contributions of many individuals, from John $A$. Weir to Wilbur Bowker, are acknowledged.
Les auteurs relatent l'histoire de la faculté de droit de l'Université de l'Alberta. Ils commencent par examiner la formation exigée des tout premiers avocats, discutent des événements qui ont conduit à létablissement de la première faculté de droit permanente de la province et suivent l'évolution de la Faculté. Ils font état des contributions importantes de nombreuses personnalités - de John A. Weir à Wilbur Bowker.

TABLE OF CONTENTS

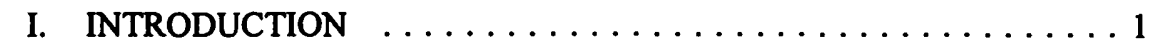

II. EARLY FOUNDATIONS $\ldots \ldots \ldots \ldots \ldots \ldots \ldots \ldots \ldots \ldots$

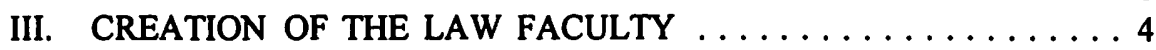

IV. ESTABLISHMENT OF THE FULL-TIME LAW FACULTY . . . 8

V. GROWTH OF THE LAW FACULTY $\ldots \ldots \ldots \ldots \ldots \ldots \ldots$

VI. THE MODERN LAW FACULTY $\ldots \ldots \ldots \ldots \ldots \ldots \ldots \ldots$

\section{INTRODUCTION}

As with many institutions in our society, the Faculty of Law at the University of Alberta can be considered a living entity. It has a past, a present and a future. Its future cannot be anticipated and its present cannot be properly understood unless there is some comprehension of its past. The following history of the Faculty is neither detailed nor comprehensive. Through text and photographs it will provide the reader with an outline of some of the leading events and personalities who have shaped the Faculty's course over the last seventy-five years since it first opened its doors to the first full-time study in law.

\section{EARLY FOUNDATIONS}

Before 1885 , the practice of law was unregulated in what was, then known as the North-West Territories. The practicing bar was small and consisted of lawyers from other jurisdictions who had come to the North-West and commenced practice without any official sanction.' However, with the enactment of an ordinance ${ }^{2}$ in 1885 to regulate admission to the legal profession, this situation changed. Legal practitioners

J.M. Law, Professor of Law, University of Alberta and Roderick J. Wood, Associate Professor of Law, University of Alberta.

As Peter Sibenik in his unpublished M.A. Thesis, "The Doorkeepers: The Govemance of Territorial and Alberta Lawyers, 1885-1928" (Calgary: University of Calgary, 1984) at 87 observes: "As there was neither a law society nor rules and regulations governing the practise of law, one simply commenced practice."

2 An Ordinance Respecting the Legal Profession, O.N.W.T. 1885, No. 10. 
were admitted on the basis of admission categories designed to accommodate those currently practicing as well as those seeking entry for the first time.

The latter group was made up of two types of applicants: an "outside stream" of lawyers already admitted to practice as either barristers or as solicitors, advocates and attorneys, elsewhere in the British empire, and an "inside stream" of students who articled, or were deemed to have articled, for a prescribed period of three years with a territorial lawyer. ${ }^{3}$ This scheme discouraged the admission of American lawyers in favour of the admission of Anglo-Canadian lawyers already admitted to practice elsewhere. ${ }^{4}$

By the turn of the century, the scheme established in the first ordinance had been changed on a number of occasions. ${ }^{5}$ As a result, lawyers seeking entry via the outside stream had to be members in good standing of a professional organization and provide testimonials as to their good character. Non-lawyers had to undergo a period in articles and pass an examination. The prescribed period in articles was set at five years for matriculants and three years for "a graduate in arts or law of a recognised university in the United Kingdom or in Canada or a graduate of the Royal Military College of Canada...." With this, the "three or five" articling regime was established.

The three or five regime was based on the contemporary English model of legal education. In England, prospective solicitors had to spend five years in articles, which was reduced to three years in the case of a university graduate in law. ${ }^{7}$ The examination requirement was also lessened for graduates as they were exempted from the preliminary, and usually a part of the intermediate, examination. ${ }^{8}$ That aside, all students were required to pass the final examination before admission as a solicitor. The educational requirements for admission to the bar were less stringent. Prospective barristers were required to "keep" twelve terms at one of the four Inns of Court." This requirement did not require residence or attendance at an educational program; it simply involved eating a certain number of dinners per term. During this time, a student often became the pupil of a barrister for the purpose of studying the practice of law, even though pupillage or apprenticeship with an admitted practitioner was not compulsory. However, like solicitors, barristers were required to pass a far from stringent final examination which required the candidate "to memorize answers to a limited number

Ibid., s. 1 .

In most cases, an applicant had to be a resident of the Territories and a British subject.

P. Sibenik, "Doorkeepers: Legal Education in the Territories and Alberta, 1885-1928" (1990) 13

Dal. L.J. 419 at 429-430. Note that the boxes appear to have been renumbered by the University of Alberta Archives sometime after the publication of his article. References in his article to Box 10 of the Tory Papers now correspond to Box 11.

$6 \quad$ The Legal Profession Ordinance, C.O.N.W.T. 1898, c. 51, s. 5(1).

7 University instruction in law was not well developed as the vocational nature of law practice conflicted with the liberal arts mission of the older Universities. See B. Abel-Smith \& R. Stevens, Lawyers and the Courts: A Sociological Study of the English Legal System, 1750-1965 (Cambridge: Harvard University Press, 1967) at 165-180; see also A. Carr-Saunders \& P. Wilson, The Professions (Oxford: Clarendon Press, 1933) at 20.

8 Abel-Smith \& Stevens, ibid. at 169.

9 As there are four terms in a year, this requirement involved a three year waiting period. 
of possible questions." ${ }^{10}$ Like the English model, the Alberta system relied largely on office experience to prepare a law student for practice. This was a vocational form of education which depended on a student's capacity for self-study and observation. Students learned largely through clerical work in their principals' office and observing others in court." This was supplemented by the study of federal and provincial legislation and a few leading texts on the common law and equity in preparation for the bar examination.

With the creation of the provinces of Alberta and Saskatchewan in 1905, the Territorial Law Society was disbanded and replaced by a separate Law Society for each province. $^{12}$ However, this did not lead to any significant changes in either the structure of professional self-governance or the regime governing admission. Students seeking entry were still required to article for a period of either five or three years and pass an examination. However, the reduced period in articles was extended to include a broader range of university degrees, i.e. medicine, science and literature, and students were allowed with the permission of the Society to serve part of their articles in a law office or law school outside of the province.

The continuance of the three or five regime did not mean that it was not without its critics. Dr. Ira MacKay, an early proponent of university legal education, outlined some of the deficiencies of the regime in a lecture to the Law Society in Calgary in 1913:

So long as our law students are allowed to gather their legal knowledge scrap by scrap in the hundred different law offices in which they serve their time, no consensus of legal opinion and honor is possible. The clerks in the offices spend most of their time doing clerical work.... The result is a profession of apprentices without principals. These clerks receive absolutely no instruction and scarcely any assistance in their work. ${ }^{13}$

He concluded that the current "system may possibly produce collectors, conveyancers, money lenders, and real estate dealers, but it cannot produce lawyers." ${ }^{14}$ To remedy

Abel-Smith \& Stevens, supra note 7 at 171-172 describe the education of the turn of the century English barrister in the following terms:

[T] The education required of barristers continued to be of a narrow professional character. According to the Law Quarterly Review, the council's educational arrangements were "not much inferior ... to an average second rate American Law School." The examination was essentially factual.... The system provided a very profitable field for the crammer and it continued because of the limited vision of existing barristers. It was possible for a hardworking student to qualify for the final examination in three months. Most barristers "had to pick up their law in chambers and offices as best they could."

As Sibenik, supra note 5 at 436 points out many students were engaged in other activities such as teaching or government work during the course of their articles. He concludes that "the most striking impression of the articling experience in the late nineteenth century was its triviality and less than full-time status." The Law Society of Alberta was incorporated by statute in 1907 by The Legal Profession Act, S.A. 1907 , c. 20 , s. 2.

13 I.A. Mackay, "The Education of a Lawyer" (delivered at the Third Annual Meeting of the Members of the Law Society of Alberta, Calgary, 18, 19 December 1913), reproduced in (194042) 4 Alta. L.Q. 103 at 110. Ibid. 
this situation, Dr. MacKay advocated at least two years of full-time university legal education. A structured, formal program of legal education would better prepare the student to cope with advances "in human knowledge, research and economics" is than would the current system of apprenticeship and self-study. ${ }^{16}$

\section{CREATION OF THE LAW FACULTY}

Soon after its opening in 1908, the University of Alberta showed interest in providing instruction in law. ${ }^{17}$ In 1909 , a special committee of the Law Society met with representatives of the University and recommended, amongst other things, that the University provide law lectures and administer the Society's examinations. ${ }^{18}$ However, this recommendation could not be implemented unless the governing legislation was changed. In 1910, The University Act was passed ${ }^{19}$ which empowered the University to enter into arrangements with professional associations, such as the Law Society, to conduct examinations on their behalf. Two years later, the Law Society of the University entered into an arrangement with respect to the Society's examinations. This arrangement, which was to continue from year to year until terminated, left the Society with a large measure of control over the conduct and content of its examinations. ${ }^{20}$ Nevertheless, the University now had a role to play in legal education and, later that year, a Faculty of Law was created. ${ }^{21}$

The creation of a Faculty of Law at the University did not mean that it assumed sole responsibility for legal education in the province. As the University's Board of Governors had refused to underwrite the cost of law lectures, they were initially

Sibenik, supra note 5 at 437.

For a number of years the Law Society had allowed students to spend up to two years at an approved law school which would count towards the five year articling period: ibid. at 438 .

At the time, legal university education was not well established in Canada. In Ontario, the profession was reluctant to share its control over legal education with the Universities and, as a result, it operated its own law school at Osgoode Hall which provided compulsory lectures to law students as a supplement to articling. However, in Nova Scotia, the Law Society had accepted an LL.B. degree from Dalhousie University in satisfaction of its requirements for admission to the bar. Moreover, university legal education had become increasingly accepted in the United States as Harvard and other elite universities established full time legal education programs. By the 1930s, a university legal education had largely supplanted articling as the means of preparation for admission to the bar in the United States. On this subject, see generally J. Willis, A History of Dalhousie Law School (Toronto: University of Toronto Press, 1979); J.P.S. McLaren, "The History of Legal Education in Common Law Canada" in Matas \& McCawley eds., Legal Education in Canada (Montreal: Federation of Law Societies of Canada, 1987) 111-145; R. Stevens, Law School: Legal Education in America from the 1850s to the 1890s (Chapel Hill: University of North Carolina Press, 1983).

Sibenik, supra note 5 at 439 . There appears to have been a more limited program of lectures organized in Edmonton prior to the creation of the Law Faculty. These were sponsored by the Edmonton Law Student's Society in 1910-11 and 1911-12 and were delivered by judges and practitioners at the Courthouse in Edmonton. See University of Alberta Archives, Tory Papers, Box 11, File 131 [hereinafter Tory Papers].

S.A. 1910 , c. 7 , s. $41(21)$.

Sibenik, supra note 5 at 440 .

Unversity of Alberta Archives, Minutes of the Board of Governors, (8 October 1912) 70-177-44 at 27. 
undertaken as a joint endeavour with the Law Society, as it provided all of the necessary funding. The Society also funded law lectures for Calgary students at Calgary College although that institution did not have degree granting powers. The lectures were given by local practitioners and were based on the Society's curriculum which consisted of required reading in a number of legal subjects.

The Law Society's decision to sponsor lectures in both Calgary and Edmonton created a competition between the two cities over the site of the province's law school. ${ }^{22}$ Calgary students, aided and abetted by members of the Calgary bar, sought to establish a law school in conjunction with Calgary College. These efforts were strongly resisted by Dr. Henry Marshall Tory, the first President of the University of Alberta, who wanted his institution to be the only one with the power to grant degrees in the province. Tory was of the opinion that the University had the upper hand in this competition as it had already created a Faculty of Law in 1912 offering the degree of LL.B. However, he sought to undermine the efforts of Calgary College and the Calgary bar by refusing to recognize, for credit, the College's law course and by making an offer in 1914 to provide law lectures in Edmonton and Calgary at no cost to the Law Society. Tory was successful in his efforts as the Law Society accepted the University's offer and the University Commission recommended, in 1914, that a second university not be established. ${ }^{23}$ In 1915, Calgary College closed its doors forever, leaving the University free "to entrench its role in academic legal education. ${ }^{124}$

With the closure of Calgary College, the University of Alberta gained a virtual monopoly over formal, academic, legal education in the province. It not only administered the Law Society's examinations, but it had assumed sole responsibility for the provision of lectures to law students in Calgary and Edmonton. ${ }^{25}$ These lectures had been made available to students enrolled in articles since 1912-1913 to support the practical experience and training attained through work in a law office. They were based on the Law Society's curriculum which was largely concerned with intermediate and final examinations on "the general principles of the common law and equity jurisprudence, the British North America Act and amendments thereto, the Statutes of the Dominion, and the Ordinances of the North-west Territories...." ${ }^{26}$ Main subjects studied were "[p]roperty, commercial law, equity, criminal law, practice and procedure, constitutional law, contracts, torts, evidence and wills." ${ }^{27}$ Even though the lectures were extensive, ${ }^{28}$ they did not constitute a full-time program of study in law as

For a more complete discussion of this competition see supra note 5 at 441-45. As Sibenik, supra note 5 at $\mathbf{4 4 3}$ points out the University Commission was established by the legislature to determine whether Calgary should be allowed to establish its own University. Ibid. at 445.

According to Sibenik, ibid. at 441, the Society's decision to turn the lectures over to the University was not universally acclaimed by students and practitioners and was probably motivated by financial pressures on the Society's finances.

23 See W.H. Johns, History of the Faculty of Law (Edmonton: University of Alberta, 1977) at 6. 
students spent most of their time working in a law office or elsewhere. ${ }^{29}$ Accordingly, lectures were delivered in the Court Houses in Edmonton and Calgary, from nine until ten o'clock in the morning and at five o'clock in the afternoon after law offices had closed for the day. These lectures primarily met the needs of urban students as those who articled in rural areas found it difficult to attend the lectures on a regular basis and would often sit the examination without the benefit of any formal instruction.

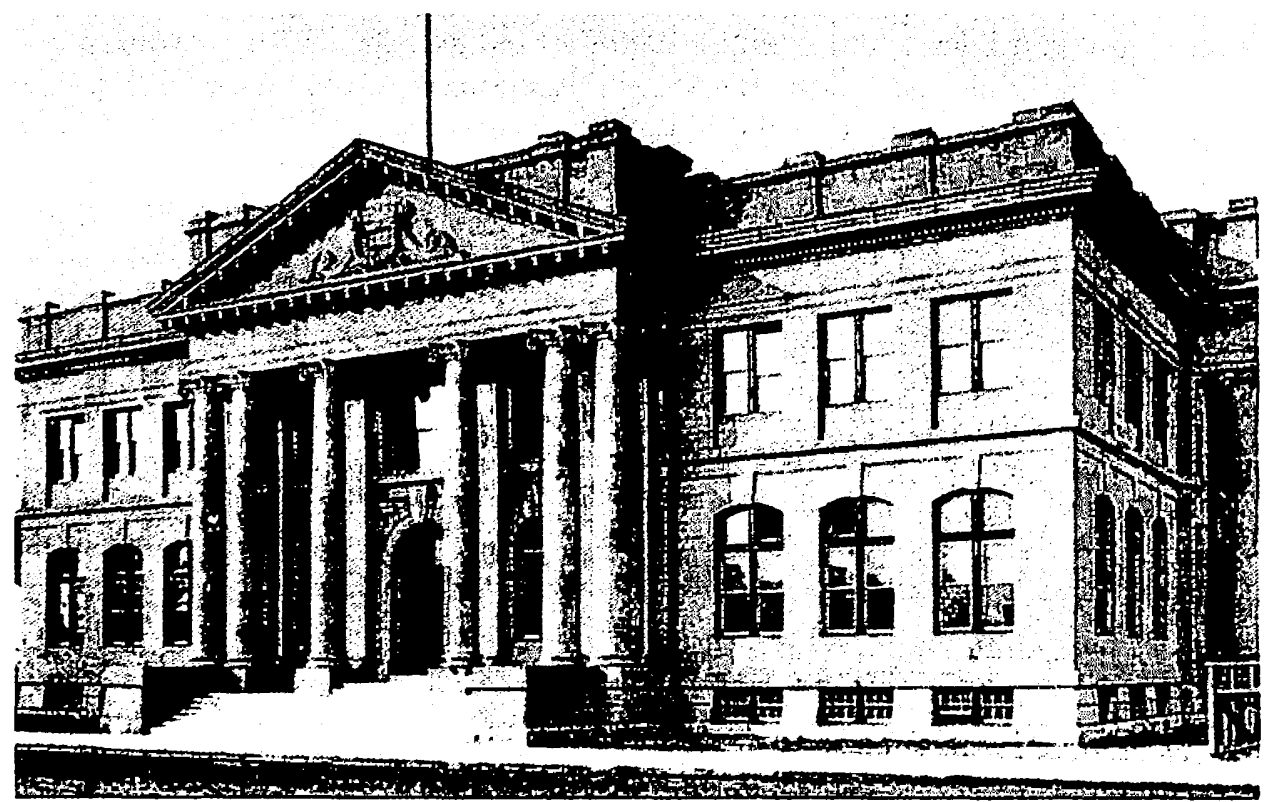

Edmonton Courthouse

1912-1921

In addition to the lectures for articling students, the Faculty also offered a program for those seeking an LL.B. degree. This program consisted of the lectures offered to articling students together with an additional set of lectures on subjects specified in the Faculty's curriculum - "mainly in history, constitutional law and jurisprudence. ${ }^{130}$ Only a few students enrolled in the LL.B. program as the degree was not required for admission to practice. However, some incentive was provided by the fact that the additional courses could be taken at the same time as the regular courses. This made is possible for students to earn an LL.B. degree through part-time courses while a law office. According to Sibenik, supra note 5 at 436-37, many students did not work full-time in their principals' offices as they pursued economic opportunities elsewhere, such as service in a government office. 
articling. With a degree, these students were then entitled to practice after only three years, rather than five years of articling. ${ }^{31}$

The lectures were provided chiefly through the endeavours of Dr. Walter S. Scott in Edmonton and Mr. W. Kent Power in Calgary. ${ }^{32}$ Dr. Scott was a graduate in Classics and English Literature from Trinity College, Dublin, and he read law at King's Inn in Dublin and Lincoln's Inn in London. In England, he served on the editorial staff of Halsbury's Laws of England before coming to Edmonton as Counsel to the Legislative Assembly of Alberta. Dr. Scott wrote several legal monographs, ${ }^{33}$ and served as a Bencher of the Law Society and Vice President of the Canadian Bar Association. He was the Faculty's "Advisor on Legal Studies" and gave many of the lectures in Edmonton. Kent Power was a graduate of Dalhousie Law School and had been a law writer in New York. In 1912, he came to Calgary to become editor of the Western Weekly Reports and the Alberta Law Reports. He wrote both a leading book on divorce and a widely used practice manual, and established the Canadian Encyclopedic Digest of Law (Western). ${ }^{34} \mathrm{He}$ served as the registrar of the Calgary branch of the University's Faculty of Law, where he gave most of the lectures. Power and Scott were assisted by several honorary lecturers headed by Justice Beck of the Alberta Supreme Court. ${ }^{35}$

In 1914, a group of eight students became the first to graduate from the University of Alberta with the degree of LL.B. ${ }^{36}$ A policy of co-educational equality was mandated from the inception of the University. ${ }^{37}$ In 1915, Lillian Ruby Clements

31 This situation was of concern to both the University and the Law Society as it allows matriculants (one year of study in a University program of Arts and Science) on the basis of a course of parttime study, to substantially reduce the five year articling period. In contrast, graduates with a university degree earned before becoming a law student had to spend three years in articles and matriculants without an LL.B., had to spend five years. To remedy this situation, the University and the Law Society agreed in 1915, that the program for matriculants seeking an LL.B. in concert with their articles should be increased in length to four years while the length of the program for graduates seeking an LL.B. should be three years, the length of the articling period: Sibenik, ibid. at 446.

$32 \quad$ Johns, supra note 28 at 5.

${ }^{33} \quad$ W.S. Scoth, Chattel Exemptions from Writs of Execution (Edmonton: Atkinson Book Co., 1917); W.S. Scoth, Homesteads and their Exemptions in Western Canada (Edmonton: Books, 1917); W.S. Scott, Torrens System Mortgages (Toronto: Carswell, 1918); W.S. Scott, The Canadian Constitution (Toronto: Carswell, 1918).

34 W.K. Power, The Law and Practice relating to Divorce and Other Matrimonial Causes in Canada (Calgary: Burroughs, 1948); W.K. Power, An Index-digest of Western Practice Cases in Civil Actions to the End of 1920 (Calgary: Burroughs, 1921); Canadian Encyclopedic Digest Western Edition (Calgary: Burroughs, 1919).

35 Johns, supra note 28 at 6 lists O.M. Biggar, E.T. Bishop, S.E. Bolton, H.F. Ewing, E.B. Cogswell, C.A. Grant, H.H. Parlee, Frank Ford and C.C. McCaul as the other honorary lecturers.

36 The records of the Registrar's Office, University of Alberta reveal that William Broad, Judd Buchanan, Richard Davidson, David Elton, Neville Lindsay, Leo Miller, Gregory Trainor and Abner Virtue were passed for the degree of Bachelor of Laws at the Third Annual Convocation, May 13, 1914.

37 The University Act, supra note 19, s. 89 provided that "no women shall by reason of her sex be deprived of any advantage or privilege accorded to male students of the university." 
became the first woman to graduate from the Law Faculty with the degree of LL.B., ${ }^{38}$ and since that time women have graduated from the Faculty in greater and greater numbers.

\section{ESTABLISHMENT OF THE FULL-TIME LAW FACULTY}

By 1920, there were two rival traditions in the education and training of lawyers in Canada: the university model and the professional model; the former "university based, with claims to academic credibility, a necessary and significant prelude to the interruption of in-service training," and the latter, "unashamedly geared to professional imperatives, with articling front and centre and the law school program and ancillary component designed to lend some system and context to the realities of practice..$^{139}$ The university model was inspired by changes instituted at Harvard Law School in the 1870's by Dean Christopher Langdell. These changes were predicated on the belief that law was a science; a subject appropriate for analysis and systemization. Accordingly, the study of law should be pursued as a scholarly discipline through a course of fulltime study at a university. With the library as their laboratory, students would learn the law through an analysis of cases, guided and stimulated by classroom instruction which featured the Socratic method of question and answer. ${ }^{40}$

Despite initial skepticism from both academics and practitioners, the Harvard approach to legal education gradually gained acceptance over the next forty years and became the model for many American law schools. By the 1920s, its virtues were being extolled by no less than the American Bar Association as part of its campaign against proprietary and part-time law schools which primarily served ethnic and working class communities. ${ }^{41}$ Within a few years, this campaign was successful and full-time attendance at an accredited university law school became the norm for admission to practice. ${ }^{42}$

With one exception, Dalhousie Law School, the university model of legal education was not initially accepted in Canada. ${ }^{43}$ This can be attributed to a number of factors depending on the jurisdiction involved. ${ }^{44}$ However, the failure to embrace the

On September 20, 1915 she also became the first woman to be admitted to the Alberta bar. See S. Petersson, "Ruby Clements, Welcoming a "Petticoat" to the Alberta Bar" (1996) 5:2 Architypes 4 (Calgary: Legal Archives Society of Alberta).

McLaren, supra note 17 at 122-23.

The Harvard approach to legal education is described in P.D. Carrington, "Hail! Langdell!" (1995) 20 Law and Society Inquiry 691. See also C.A. Wright, "The University Law Schools" (1950) 28 Can. Bar Rev. 140.

J.S. Auerbach, Unequal Justice: Lawyers and Social Change in Modern America (New York: Oxford University Press, 1976) at 74-129. The profession's view of proprietary and part-time law schools was also shared by members of the elite legal academy; see H.F. Stone, "Some Phases of American Legal Education" (1923) 1 Can. Bar Rev. 646 at 657-61, where the Dean of Columbia Law School decried the "evil influence" of proprietary law schools and increased immigration.

Stevens, supra note 17 at 92-103, 112-23.

Dalhousie Law School was established in 1885 on the basis of the Harvard model. See McLaren, supra note 17 at $120-21$.

For example, in some jurisdictions there were no universities to provide such instruction. 
university model can be primarily attributed to the large measure of control exerted over legal education by the profession. Until the 1920 s the profession remained wedded to period of practical training, articles, as the means of preparation for practice. Formal lectures, such as those offered by the University in conjunction with the Law Society of Alberta were not designed to supplant articles as the primary means of preparation but to supplement them. ${ }^{45}$

It should be noted that the move to a program of full-time university legal education in the early 1920s was very much a prairie phenomena. ${ }^{46}$ The Universities of Manitoba and Saskatchewan also implemented such programs at this time, although Manitoba reverted to the professional model in $1930 .{ }^{47} \mathrm{~A}$ major benefit of the university model was that it gave students more preparation time and allowed them to carry a heavier courseload. It also permitted the use of the Socratic method of instruction in which students were expected to come to class prepared to participate in a more thorough and sophisticated analysis of the caselaw.

The most pressing task facing President Tory immediately following the reorganization of the Faculty of Law was the recruitment of a Law Dean. Tory felt that the ideal candidate should be a Canadian with training at the Harvard Law School. In this regard, Tory was aided by Harvard's Dean of Law, Roscoe Pound, with whom he frequently corresponded. ${ }^{48}$ Although offers were made to Ivan Rand and P.E. Corbett, both men declined..$^{49}$ Kent Power and Walter Scott were interested in obtaining the position, but neither seemed to fit the mould. ${ }^{50}$ Further searching produced no results. Finally, Tory decided to make a temporary appointment of a Law Dean after Dean Moxon of the College of Law at the University of Saskatchewan alerted him to the possibility of recruiting a young graduate by the name of John Weir. ${ }^{51}$

This was also true in Ontario where the profession revived its school of law in the 1880 s to provide an extensive part-time program of lectures to students enrolled in articles.

See W.W. Pue, "Common Law Legal Education in Canada's Age of Light, Soap and Water"

(1996) 23 Man. L.J. 654 at 662-74.
See E.K. Williams, "Legal Education

President Tory to Dean Roscoe Pound, June 7, 1921, Tory Papers, Box 11, File 68-9-122:

I am in Montreal on my way home and have not yet succeeded in getting a head for my

Faculty of Law ... I have been in touch with several Oxford men, but have not yet found one

to my liking. Would still like to get a man with Canadian Harvard training, if it were possible to do so.

Ivan Rand, who was then practicing law in Moncton, was later appointed to the Supreme Court of Canada. P.E. Corbett, then a Fellow of Souls' College in Oxford, expressed interest, but was intensely involved in Geneva with the League of Nation's Committee on the Permanent Court of International Justice. Corbett to Tory, August 23, 1921, Tory Papers, Box 11, File 68-9-122.

Sibenik, supra note 5 at $\mathbf{4 6 0}$.

Dean Moxon to Tory, Sept. 7, 1921, Tory Papers, Box 11, File 68-9-122:

For a good sound man without any real teaching experience who would fill in for one year I would recommend John Weir of Saskatoon, a brilliant graduate here who has taken two years at Oxford obtaining the degree with first class honours.... 
John Alexander Weir thus became the Acting Dean and the Faculty's first full-time teacher. ${ }^{52}$ Weir was born in North Dakota, and moved to Regina then Saskatoon as a child. He completed his B.A. and LL.B. at the University of Saskatchewan, where he was awarded the Governor-General's Gold Medal. He was chosen for a 1914 Rhodes Scholarship and, after three years of service in the R.A.F. as a Flying Officer, he earned a Bachelor of Arts with first class honours from Oxford. Weir became Dean of Law in 1926 and continued in that capacity until his untimely death in 1942. Wilbur Bowker, later Dean of Law, described Dean Weir as "a master of the hypothetical case and the Socratic question." ${ }^{53} \mathrm{He}$ is remembered by many of his students for his genius and his humanity. He carried an enormous workload, ${ }^{54}$ and when he died his courses had to be divided among seven part-time lecturers. ${ }^{55}$

The bond between the Faculty of Law and the larger university community was cemented by housing the law school on the university campus. This produced a change in attitude which was commented upon by Dean Weir in a Report to the Senate:

Complaints were formerly made that the law-students did not coalesce with the general body of the students and that the interest they took in student life was of the slightest. Since the introduction of a full-time lecture system and the coming of law-students into residence, these complaints have ceased. During the past year students of this faculty have filled the positions of President of the Students' Union, Chief Justice of the Students' Court, Editor of the Gateway, Chairman of the House Committee and President of the Senior Class. ${ }^{36}$

See M.M. Macintyre, "John Alexander Weir, K.C., B.A. LL.B., 1894-1942" (1942-45) 5 Alta. L.Q. 1.

2020 Anniversary Celebration Program (Faculty of Law, 18-19 September 1992) at 9.

54 When Kleven, the only other full-time faculty member, left the Faculty of Law in 1924 in order to take up a position at the College of Law at the University of Saskatchewan, Weir took over most of Kleven's teaching responsibilities as well. Alfred Z. Reid, the celebrated chronicler of North American law schools commented upon this overloading in Present-Day Law Schools in the United States and Canada (New York: Merrymount, 1928) at 373:

The last named institution [Alberta] can find no valid defence in the fact that its plight in 1924 was due to the unexpected call of one of its two full-time instructors to another school. An emergency of this sort in a properly organized faculty can be met by either or both of two devices: by increasing the burden on the remaining instructors to a figure that, regarded as a temporary measure, would not be unreasonable; or by postponing until the following year a considerable portion of the work regularly offered. This school was already operating with a teaching load of fourteen hours weekly for each of the two instructors; and with postponed work, as announced for 1924-25, aggregating seven year-hours. This left no margin upon which to draw. Hence the incredible burden placed upon the single surviving full-time teacher.

Weir continued to teach a very heavy load even after the staffing emergency had ended. In 1926-27 he was scheduled to teach the following courses: instruction in Contracts (3 hours); Torts 1 ( 3 hours); Criminal Law ( 2 hours); Sales ( 2 hours); Evidence 1 ( 2 hours); Evidence 2 (1 hour); Constitutional Law (3 hours); Wills (1 hour - First Term); Sureties (2 hours - First Term). See Proposed Lectures in Law during 1926-27, Tory Papers, Box 11, File 68-9-123. 
The heart of the Faculty was the Law Library on the second floor of the south wing of the Arts Building. ${ }^{57}$ Each student had a chair and desk space, with the modest collection of law reports, journals and statutes which comprised the law library along its walls. ${ }^{58}$ Embracing the university model of legal education did not mean that the Faculty's ties with the practicing bar were to be severed. The Faculty of Law received immeasurable help from Edmonton judges and "overtown" lawyers including George Steer, Frank Ford, William Dixon Craig, H.H. Parlee and S.W Field who served as sessional lecturers.

The Faculty had only one other full-time member, and did not increase in size until after the Second World War. Victor E. Kleven, a Rhodes Scholar, served until 1924. He left and his place was taken by Sigvald Nielsen, the Gold Medalist of the Faculty's first full-time class. When Nielsen left in 1930, he was replaced by Dr. Malcolm M. MacIntyre, a Mount Allison graduate who had obtained his LL.B. and later his doctorate at Harvard. He was noted as being a great teacher of torts and a sound pragmatist after his celebrated teacher Roscoe Pound. ${ }^{59}$ Like Dean Weir, his contributions to legal journals helped establish the scholarly tradition in legal writing in Canada. In 1934, he founded the Alberta Law Quarterly, a predecessor of the Alberta Law Review. Dr. MacIntyre served as Dean of Law from 1942 until 1945, when he returned to practice in New Brunswick. Several years later he joined the newly established Faculty of Law at the University of British Columbia.

During the 1921-22 academic year, the Law Faculty did not have a law library. The executive of the Law Club (a predecessor to the Law Students' Association) reported in the Evergreen and Gold, 1921-22 (Edmonton: University of Alberta) at 39 that "[t]he barristers, long-suffering individuals, have cheerfully permitted us to 'romp' to our heart's content in the Court House Library, but next year we hope to have a 'playground' of our own." The following year they reported in Evergreen and Gold, 1922-23 (Edmonton: University of Alberta) at 83 that "[t]he most pleasant event of the year was the advent of a real 'law library' all of our own, where no barristers trespass and students reign supreme."

Wilbur Bowker describes the Law Library in Room 206 of the Arts Building in 2020 Anniversary Celebration Program, supra note 53 at 11 :

Each student had a chair and desk space - third year by the lighted front windows, second in the middle and first towards the west wall. The entire library - law reports, texts and journals, was along the walls. There were no case books apart from Falconbridge on Sales and Scott on Trusts. 


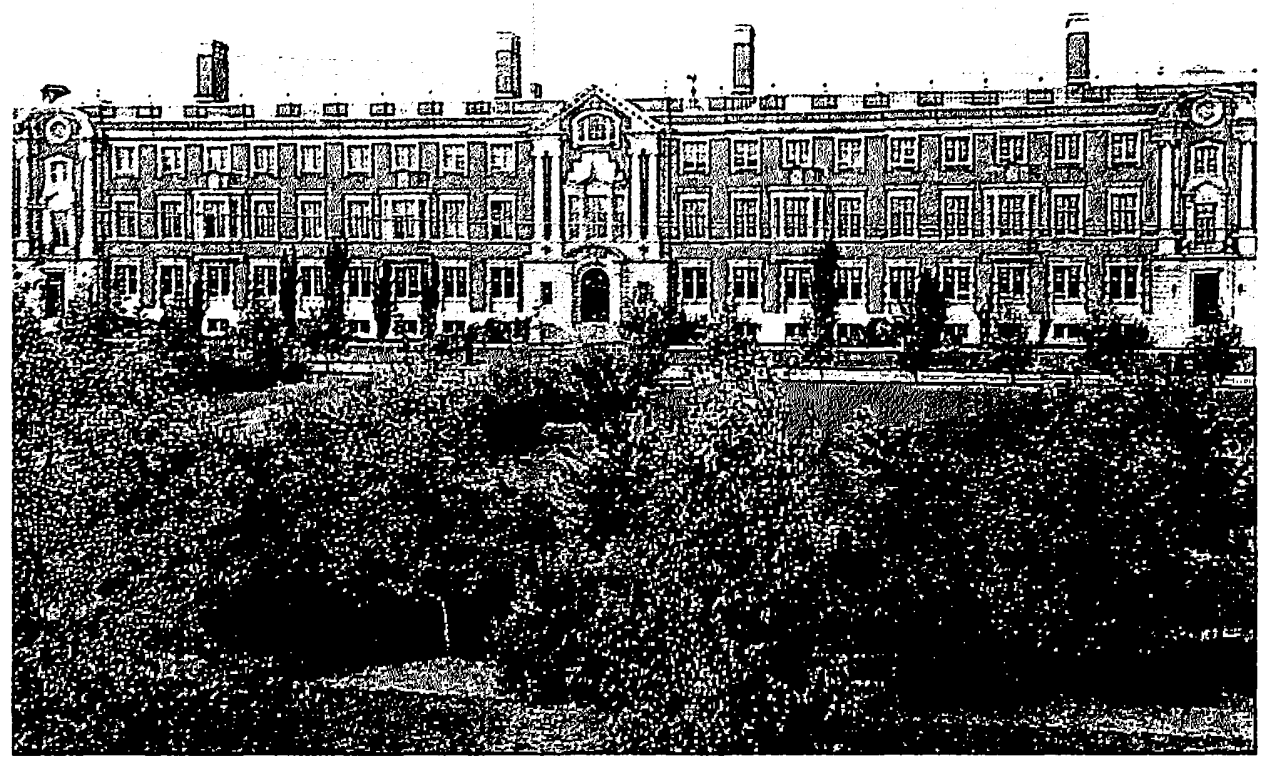

Arts Building

1921-1951

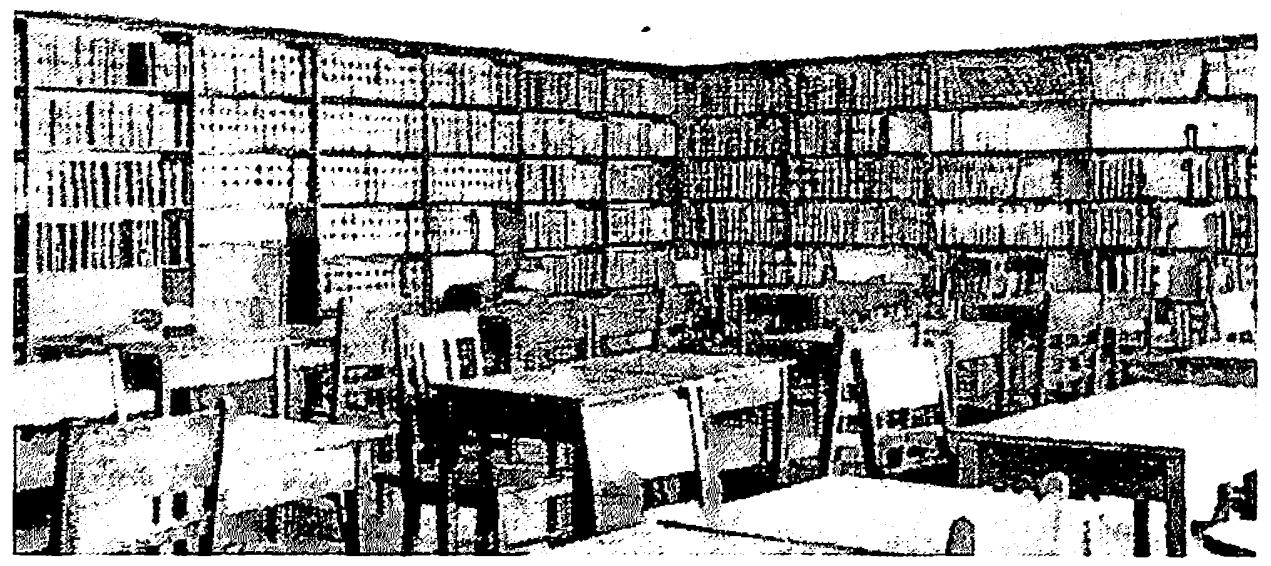

Law Library and Classroom

(Arts Building) 


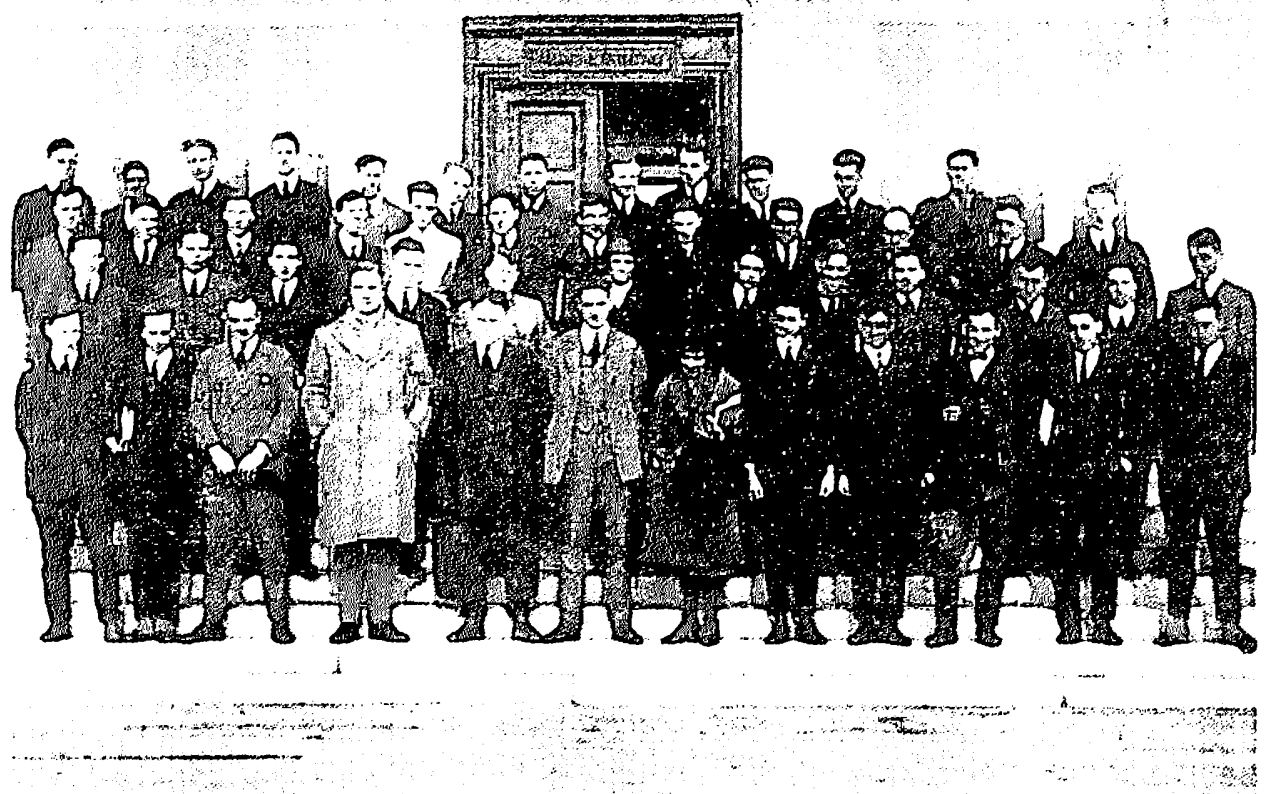

First and second year law class (1923)

(Kleven fourth from left, Weir fifth from left)

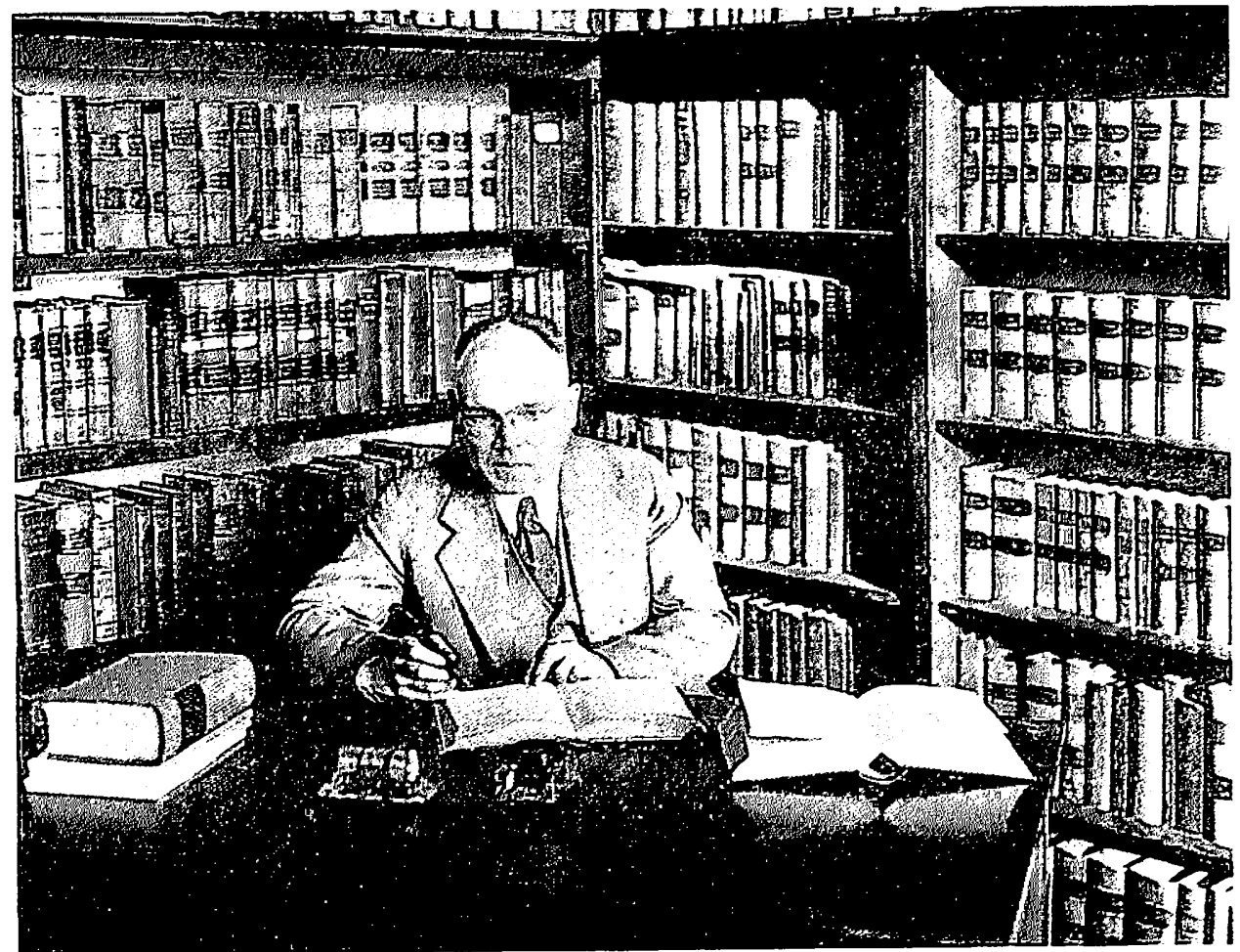

Dean John A. Weir 
The curriculum did not change radically following the reorganization of the Faculty in $1921 .{ }^{60}$ Courses continued their focus on practice, property, equity, legal history, evidence, commercial law, jurisprudence, contract, torts and constitutional law, and students were evaluated on the basis of a rigorous set of four hour examinations. ${ }^{61}$ The key difference lay in the adoption of the case method. ${ }^{62}$ Instead of studying from legal treatises, students gained their knowledge from the raw material of the leading cases presented in well-organized casebooks. The case method would, it was argued, "establish in the student's mind a ... capacity for legal reasoning and not a slavish following of the decisions." ${ }^{163}$ Mandatory moot court exercises were also introduced in order to improve the students' research and rhetorical abilities and to reinforce the skills and knowledge acquired through the case study method. ${ }^{64}$

The law school remained relatively small during this period. The first entering class of 1921, about twenty-five in number, was also the largest. Over the next quarter century most classes contained fewer than twenty students. Enrolment fell to an all-time

The Faculty adopted the model curriculum proposed by the Canadian Bar Association in 1920: see Proceedings of the Canadian Bar Association (1920) 152. The model curriculum was not designed to mandate the content of legal education across Canada; it was prepared as a flexible standard to facilitate the free movement of law graduates between the provinces. McLaren, supra note 17 at 124-25 states that in concept it

was a compromise between the two existing models of legal education. It provided for a wide range of intensely practical and procedural courses, but at the same time preserved, albeit as options, courses in legal history and theory, and placed some emphasis upon Constitutional Law.

62 The establishment of the university model of legal education, with its case study method, at the expense of the professional model was not acclaimed by all members of the profession. O.M. Biggar, K.C., a leading member of the bar, commented in "Legal Education Again" (1923) I Can. Bar Rev. 864 at 867:

To reintroduce at least partially a truly practical method of approach seems, however, not to be impossible, if it is thought desirable.

Is it desirable? The accurate mapping of the field of legal principle, the analysis of cases, the consideration of the limits of the operation of rules of law and the effect of their conflict may tend to increase the supply of new-fledged lawyers capable of writing head notes to reports of cases, of compiling digests and of writing articles for the Canadian Bar Review. These are capacities by no means to be despised, but are they those for the development of which law societies should spend money contributed by the profession or upon which they should insist with more emphasis than upon other qualifications? Their cultivation is in accordance with the best tradition of university education, and if law is looked upon as a pure science, like mathematics or astronomy, there is nothing to be said against it. The academicians seem to take this view, but few practicing lawyers will be inclined to accept it; they know that the law is in truth a very practical science, that, to use an engineering simile, the lawyer who has the skill of a good motor mechanic is more useful in the practice of law than one with the learning enabling him to calculate mathematically the advantages and disadvantages of decreased cylinder diameter but incapable of adjusting an erratic timer. The technical aptitude is first in importance, the science, though useful and important, is secondary. The example of the great American schools of law must not be allowed to mislead. They are not professional schools, except by courtesy; their function is primarily an academic one. 
low near the end of the Second World War with only nine students registered in all years in 1944-45.

\section{GROWTH OF THE LAW FACULTY}

With both Weir and MacIntyre gone, the onerous task of maintaining the Faculty during a difficult period fell upon George $\mathrm{H}$. Steer, a leading Edmonton practitioner. Steer had graduated from Queen's and had articled in Edmonton. He taught as a sessional lecturer from the earliest days of the Law Faculty, and was involved in several key constitutional cases in the $1930 \mathrm{~s}^{65}$ Steer was appointed Acting Dean in 1944. This was a critical moment in the life of the Faculty. Enrolment had dwindled to only a handful, and key personnel had been lost. The process of renewal and rebuilding began in 1945 when Steer recruited Wilbur F. Bowker to teach at the law school on a full-time basis.

Bowker articled and then later practised with Steer's firm. He became Acting Dean in 1947, and Dean of Law in 1948. Wilbur Bowker has maintained an association with the Faculty of Law for over fifty years as Dean, as Director of the Institute of Law Research and Reform and finally as a Professor Emeritus. ${ }^{66} \mathrm{He}$ is remembered by Trevor Anderson, a one time colleague and later Dean of Law at Manitoba, for his meticulous legal scholarship and for his complete lack of arrogance as a teacher whose object was "to help the students make themselves into lawyers who were skilled, rational, sensitive and responsible. ${ }^{167}$ His contributions to the province, the university and the legal profession are too many to recount here. ${ }^{68}$ They include service as an Alberta Commissioner on the Conference of Commissioners on Uniformity of Legislation from 1952 to 1976, and as President of the Canadian Association of Law Teachers in 1955-56.

In 1947, Dr. Alexander Smith, who taught as a sessional during the War years, was named Associate Professor and served the Faculty well until his retirement in 1973 . He articled with the law firm of George Steer in 1941 and obtained his Doctor of Jurisprudence from Stanford University in 1955 . He also made a major contribution to constitutional scholarship with his book on the commerce power. ${ }^{69}$ Trevor Anderson provides a vivid recollection of Dr. Smith's classroom presence:

All his students will recall the skilful design and sequence of his questions, his insistence that they "wrestle with angels," his impatience with slovenliness or neglect, his warm endorsement for work well done, his infectious and ever-renewed enthusiasm for the challenges of the law. Sometimes the

See W. Bowker, "Fifty-five Years at the Alberta Bar: George Hobson Steer, Q.C." (1982) 20 Alta. L. Rev. 242 at 262-267.

S6ee D.T. Anderson, "Wilbur Fee Bowker: In Appreciation" (1976) 14 Alta. L. Rev. 199.

67 Ibid. at 208.

68 Ibid. at 210-11.

69 A. Smith, The Commerce Power in Canada and the United States (Toronto: Butterworths, 1963). 


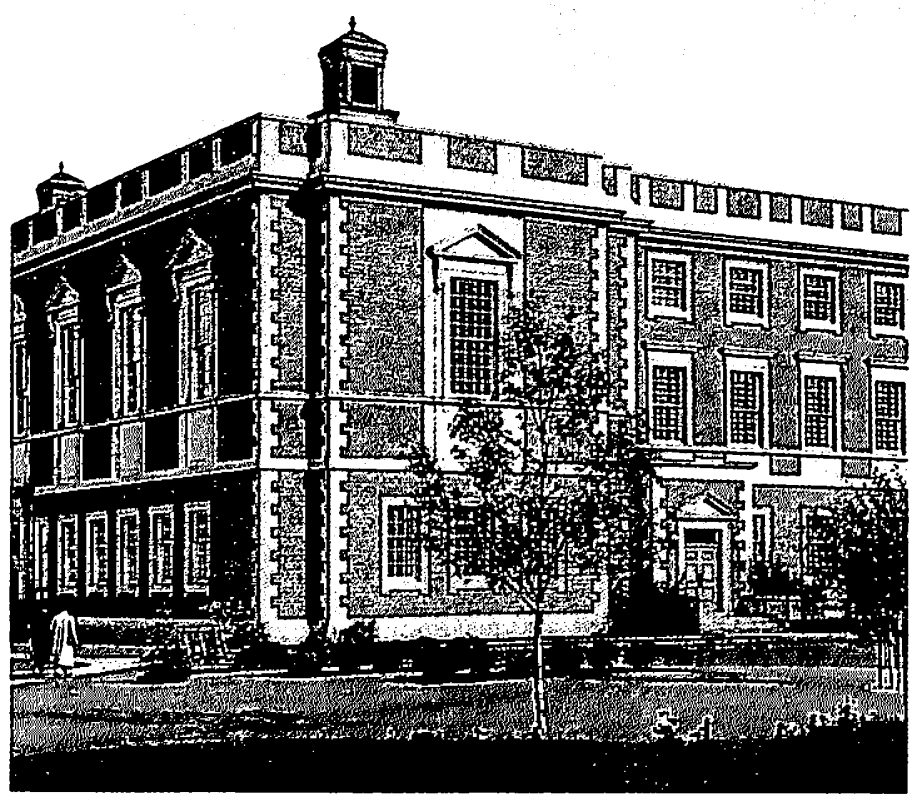

Rutherford Library

1951-1971

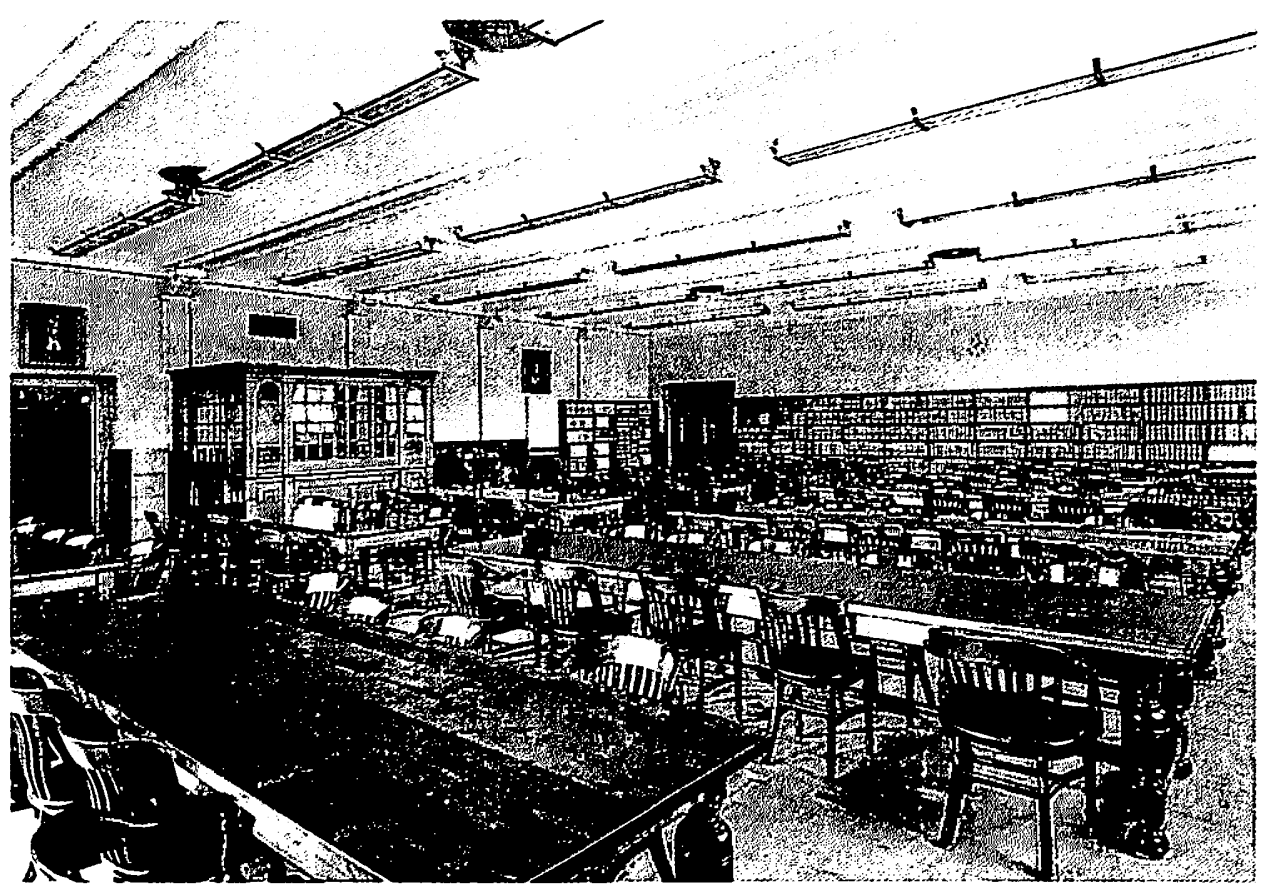

John A. Weir Memorial Library

(Rutherford Library) 


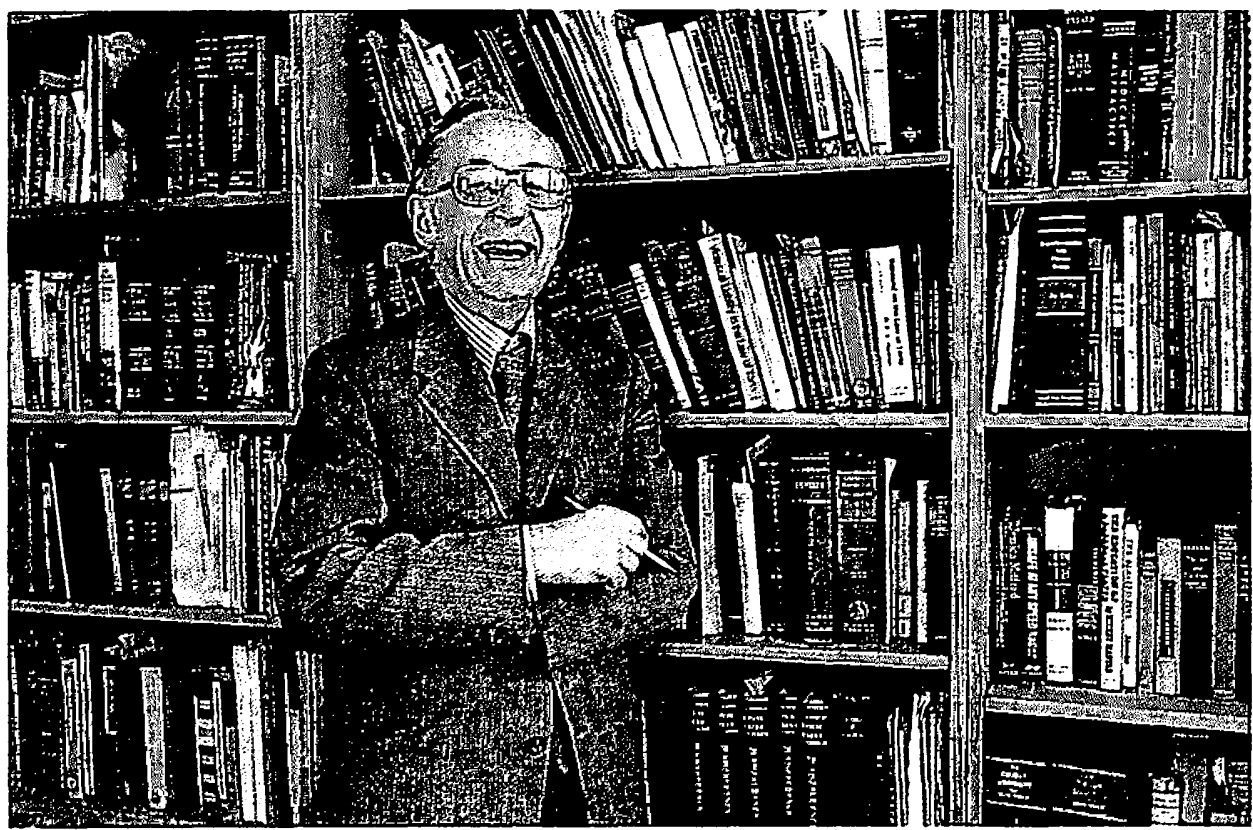

Dean Wilbur F. Bowker

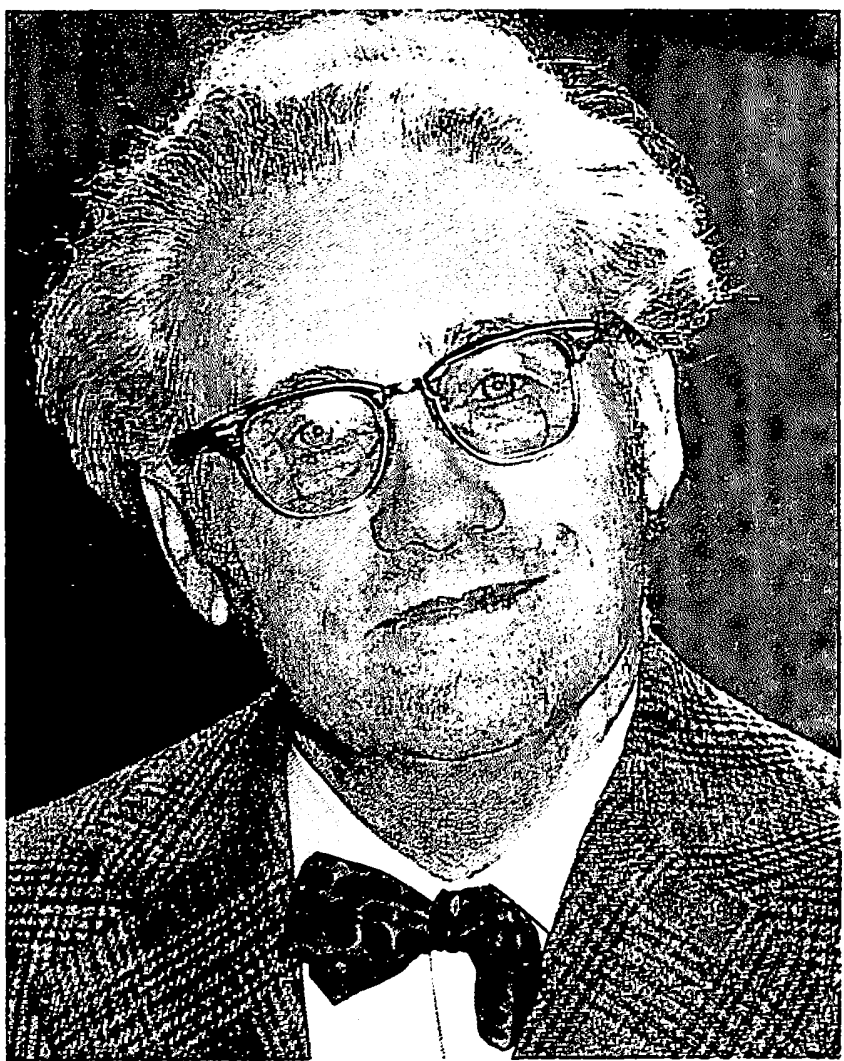

Dr. Alexander Smith 
lightning would flash and the thunder roll, but when the sun shone, it warmed the room. His students first feared, then loved him. He pried open their minds, and gave them glimpses of the infinite. ${ }^{70}$

Dean Bowker was destined to steward the Faculty through a period of growth and consolidation. The full-time teaching complement expanded. He hired additional fulltime faculty, including William Reed, Andrew Thompson, Douglas Sherbaniuk, A.B Weston, William Angus, Trevor Anderson, Ivan Head, Frank Jones and Fred Laux. The Faculty was also well served by a distinguished group of sessional lecturers, including William Sinclair, William Hurlburt and David C. McDonald.

The size of the Faculty began to swell following the end of the Second World War when veterans began legal studies in preparation for joining the post-war economy. In 1950-51 enrolment reached a post war high of 142. This placed an intolerable strain on the library and study space allotted to the Faculty. Fortunately, that same year Cameron Library was built and the Law Faculty was assigned space on the newly vacated first floor of the Rutherford Library. Mr. Justice Jean Côté of the Alberta Court of Appeal has described the atmosphere of "the magnificent Weir Law Library" in the early 1960s:

There students occupied permanent chairs, stored their notes, debated law, chatted, heckled outsiders, played ping pong using the Probate Reports, and read law reports. They created Stephen Leacock's ideal university in the Library. It embodied the corporate life of the Faculty, much as the Four Courts Library had housed the Dublin Bar. To this day, Alberta graduates of that era feel more comfortable and productive in a law library than in an office. Can any law school make a finer claim? ${ }^{71}$

In 1964, the Faculty was given offices, classrooms and a moot courtroom on the third floor. The Weir Memorial Library was significantly upgraded through the acquisition of a much broader range of monographs and journals, and staffed by a cadre of professional law librarians.

The law curriculum remained relatively static ${ }^{72}$ until major changes were introduced in the mid-1960's. A major expansion in courses permitted second and third year students to choose from among a variety of options in addition to the required courses. ${ }^{73}$ This tradition remains to this day. To this end, students are required to take a set of core courses which provide a grounding in the major areas of law and practice, but are also encouraged to develop and explore their own interests in law. In 1965 a graduate program leading to the Master of Laws degree was established with an emphasis on oil and gas law. The program was later expanded to facilitate graduate

Supra note 66 at 205. See also W.F. Bowker, "In Memoriam: Professor Emeritus: Alexander Smith (1911-1991)" (1992) 30 Alta. L. Rev. 425.

72020 Anniversary Celebration Program, supra note 53 at 11.

12 This is not to say that the curriculum remained completely unchanged. Courses in Taxation and Administrative Law were added during the deanship of Macintyre. See W.H. Johns, supra note 28 at 9.

7) See e.g. A.R. Thompson, "The Course in Land Titles at the University of Alberta" (1963) 3 Alta. L. Rev. 117, which describes the development of a path-breaking course in land titles which at the time was regarded as "an oddity in the curricula of Canadian and United States law schools." 
study in most major areas of law. Many of these graduates have obtained academic appointments throughout Canada and the Commonwealth.

\section{THE MODERN LAW FACULTY}

By the mid-1960s the Faculty of Law had again outgrown its facilities. Increasing student enrolment, a corresponding increase in the full-time faculty, together with the growth in library holdings provided the impetus for another relocation of the Faculty. In 1972, the present Law Centre was officially opened, consolidating administrative and faculty offices, institutes, students' groups and the library into a building specifically designed for the Faculty. Then Dean of the Faculty, Gerald Fridman, remembered the opening as "a glittering occasion graced by the presence of distinguished judges and scholars from various parts of the Commonwealth." ${ }^{74}$ The Law Centre is now home to 500 law students and twenty-five full-time members of Faculty of Law. Close ties to the legal profession are maintained by virtue of the contributions of more than fifty members of the judiciary and practicing bar who annually serve as sessional lecturers.

The Weir Law Library, located in the heart of the Law Centre, continues to occupy a central position in the lives of the students and professors who work in the Law Centre. It is the Faculty's primary research laboratory and most prized resource. Containing over 300,000 volumes and maintaining nearly 4,000 serial publications, the collection is one of the largest in Canada. A microcomputer lab containing twenty-two networked computers was installed in the library in 1988 and upgraded in 1995 in order to provide students with the most up-to-date computer research skills. Full Internet access is provided and students may also connect to the campus library system to search on-line databases, the library collection or the CD ROM collection.

The Faculty's long-standing commitment to legal research led to its association with a number of research institutes, beginning in 1968 when Dean Bowker resigned to assume the Directorship of the newly established Institute of Law Research and Reform (now the Alberta Law Reform Institute). The Institute, created through an alliance of the University, the Law Society of Alberta and the provincial government, continues to be housed in the Law Centre. And since 1968, three more leading research institutions have aligned themselves with the Faculty. The Health Law Institute (established in 1977), the International Ombudsman Institute (established in 1978) and the Centre for Constitutional Studies (established in 1986) are all located in the Law Centre and each makes a major contribution to legal research and scholarship through the publication of scholarly journals and the organization of academic conferences and lecture series.

Four Law Deans have served the Faculty over the past three decades: Gerard LaForest (1968-1970); Gerald Fridman (1970 to 1975); Frank Jones (1976-1986) and Timothy Christian (1987 to the present). A number of important initiatives were implemented during this period. In 1971, Student Legal Services commenced operations. It was founded by the students of the Faculty of Law as a non-profit 
[VOL. XXXV, NO. 1 1996]

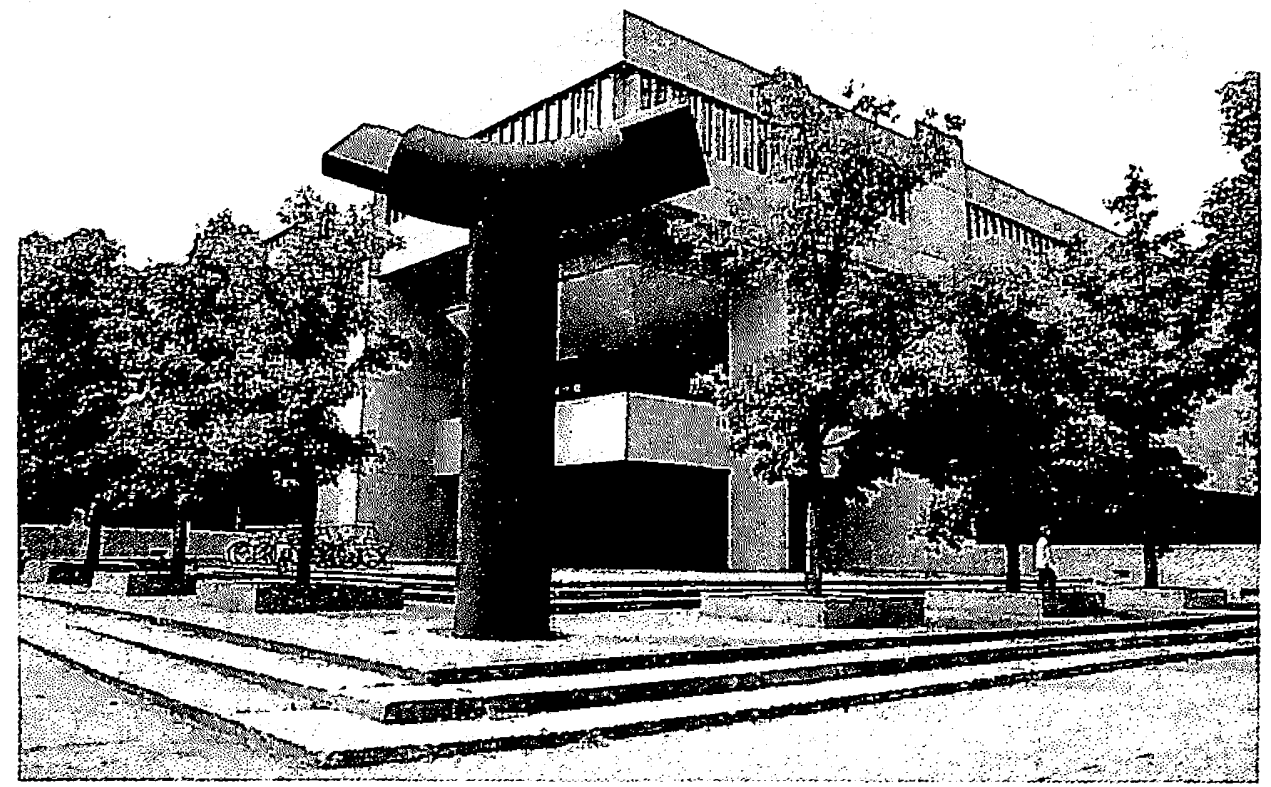

Law Centre

(1971-present)

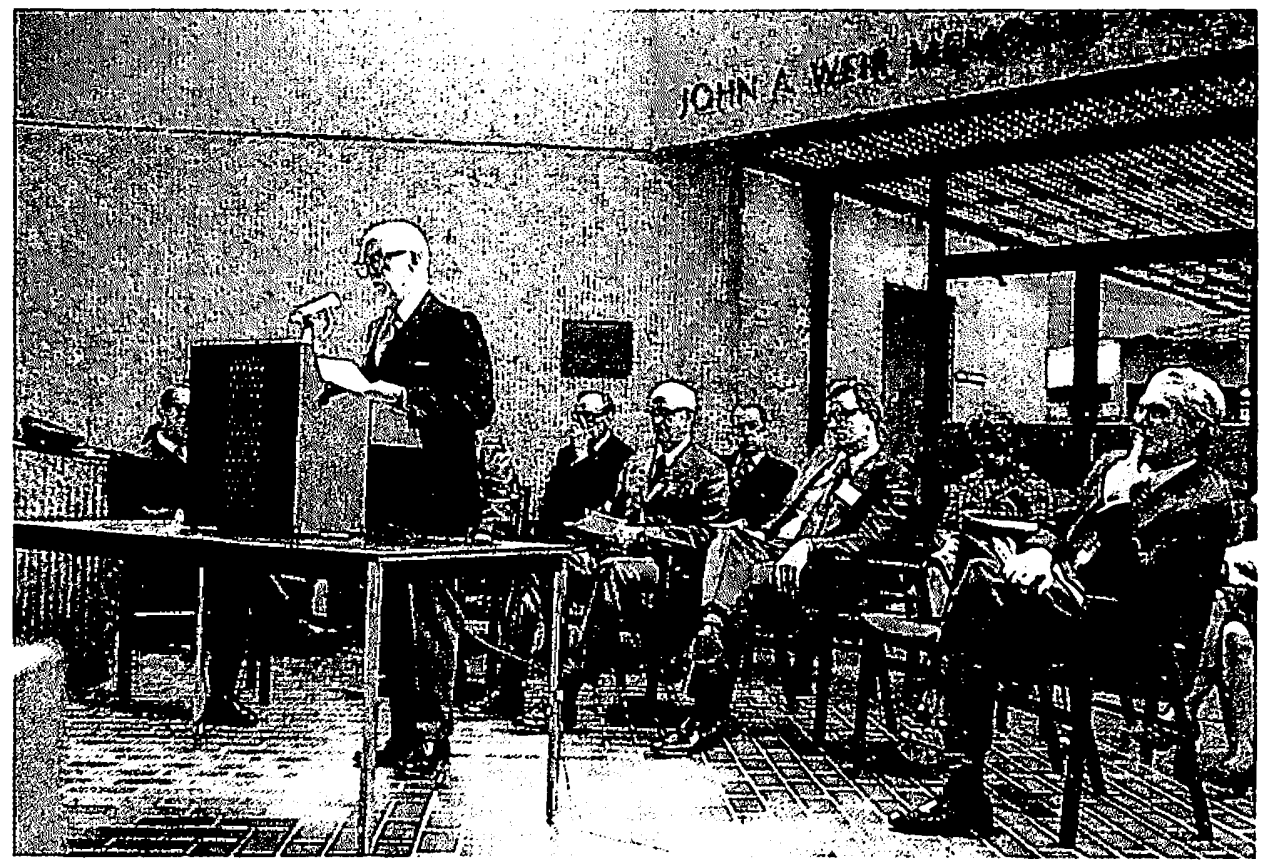

Official opening of the Law Centre, May 4, 1972

Left to right: Gerald Fridman (behind podium); S. Bruce Smith (at podium); Wilbur Bowker; Grant McEwan; Eric McQuaig; James Foster; unidentified; Bora Laskin 


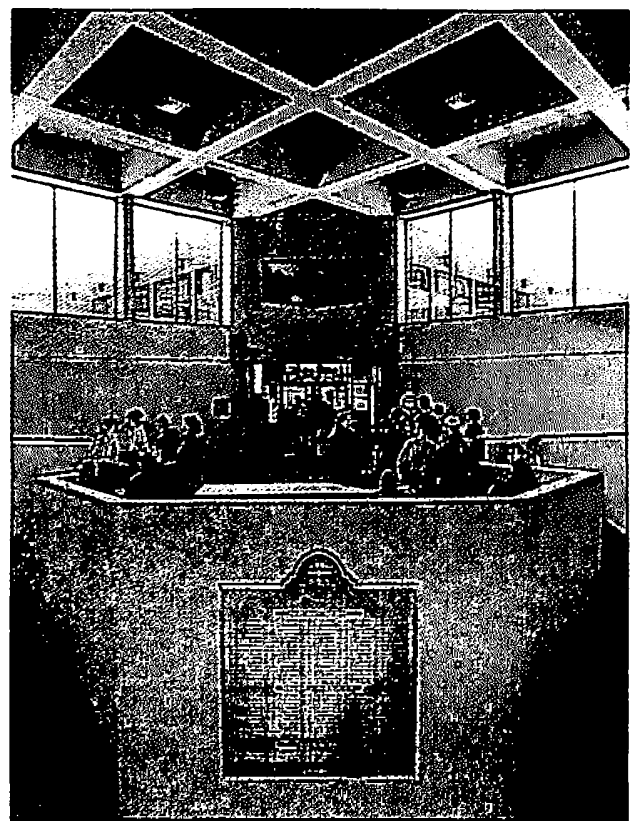

Entrance to the John A. Weir Memorial Library (Law Centre)

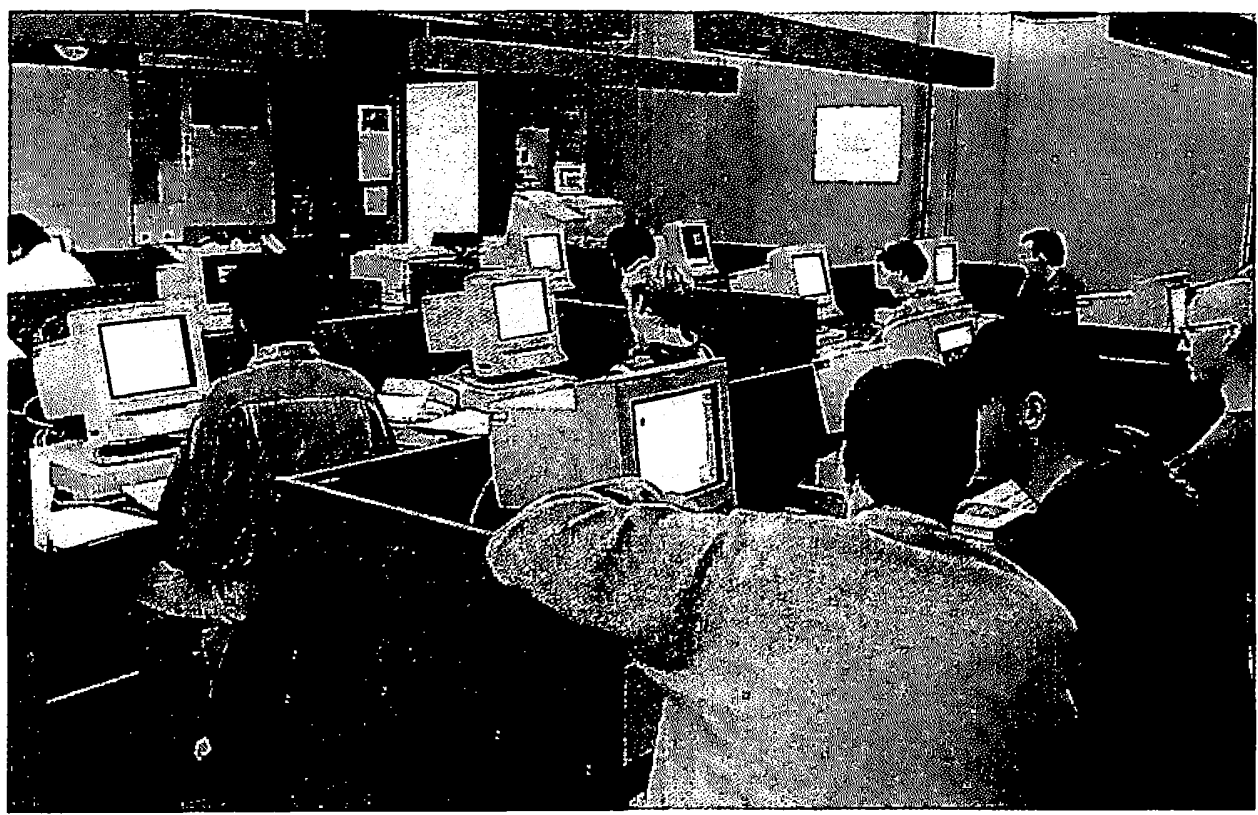

Microcomputer Lab

(John A. Weir Memorial Library) 
charitable organization to provide assistance to people who do not qualify for legal aid. ${ }^{75}$ The Indigenous Law Program was established in 1991 to redress the underrepresentation of Aboriginal lawyers in Canada by recruiting qualified candidates and providing personal and academic support to those enrolled in the program.

The curriculum continued to expand with new offerings such as International Business Transactions, Aboriginal Peoples and the Law, Environmental Law and Client Counseling to mention only a few. However, whereas many Canadian law schools have made all of the second and third year courses optional, ${ }^{76}$ the Law Faculty has continued to require its students to take a set of core courses in the belief that it will "instil in each student a strong foundation in legal knowledge, lawyering skills and professional values." ${ }^{\text {"77 }}$

Although the increase in the size of the entering class was perhaps the most visible change during this period, there have been a number of equally significant demographic changes in the composition of the student body. The age and prior educational experience has steadily risen. Today, the average age of first year students exceeds twenty-six years, and the vast majority also hold degrees in other disciplines. In the past, the number of men admitted into the Faculty has always exceeded the number of women, although the difference in numbers has been steadily shrinking. This year, a majority of the entering class of law students are women. ${ }^{78}$ The competition amongst students to gain entry into the Law Faculty is much stronger than in the past, ${ }^{79}$ and the search for articles following the LL.B. has become less easy. In response to this changing market, the Faculty of Law has increasingly shifted its resources so as to assist in the placement of its students.

Universities in Alberta were among the first in Canada to undergo deep budgetary cuts as part of a larger provincial effort to eliminate the deficit and reduce the debt. Over the past three years, the operating budget of the Law Faculty was reduced by over 15 percent. $^{80}$ This led to the launch of Law Campaign 75 in 1995, which to date has

In 1994, the offices of SLS were relocated from the Law Centre to Emily Murphy House in order to accommodate the construction of the John V. Decore Centre for Alternative Dispute Resolution. The house, located a short distance away from the Law Centre on the university campus, is the former residence of Emily Murphy, the noted writer, advocate in the women's rights movement and first woman police magistrate in the British Empire.

The law schools at the University of Toronto, York University, University of British Columbia have no required upper year courses. The University of Alberta has a heavier number of required courses than most of the other Canadian law schools.

Faculty of Law Brochure, 1997-98 at 26. The required courses in second year are Administrative Law, Company Law, Evidence and a choice between Jurisprudence or Legal History, while those required in third year are Civil Procedure, Conflict of Laws and Professional Responsibility. The admission statistics for 1996-97 show that 86 women (52.7 percent) and 77 men (47.3 percent) gained admission to the Faculty of Law. The admission statistics for 1996-97 indicate that there were 837 applications received and 163 offers of admission accepted. 
raised over $\$ 3.5$ million in donations, pledges, and bequests for the Faculty. ${ }^{81}$ Some of these financial resources have been devoted to expanding and enhancing the Law Centre's physical plant, including an additional 3,000 square feet which will house a multi-use, technologically advanced meeting and teaching space as well as a reading room electronically linked to the internet. Other projects supported by Law Campaign 75 include the John V. Decore Centre for Alternative Dispute Resolution which will enable the Faculty of Law to assume a strong role in the important area of A.D.R. and an enhanced moot court program which will provide students with the opportunity to represent the Law Faculty in regional, national and international moot court competitions.

The first seventy-five years of the Faculty's history has been written. It embodies the contribution of numerous men and women committed to the ideal of university legal education and legal scholarship. With this proud tradition in place, the Faculty is poised to meet the unknown challenges of the next seventy-five years.

si The campaign is named in honour of the 75th anniversary of the establishment of the Faculty of Law in 1921 as a full-time university faculty. 